\title{
Sistem Penjejak Pipa pada Balon Udara dengan Menggunakan Kamera dan Kontrol Logika Fuzzy
}

\author{
Dion Hayu Fandiantoro, Muhammad Rivai, dan Rudy Dikairono \\ Jurusan Teknik Elektro, Fakultas Teknologi Industri, Institut Teknologi Sepuluh Nopember (ITS) \\ J1. Arief Rahman Hakim, Surabaya 60111 Indonesia \\ e-mail: dionhayu@gmail.com,muhammad_rivai@ee.its.ac.id, rudydikairono@ee.its.ac.id
}

\begin{abstract}
Abstrak - Balon udara merupakan salah satu jenis Unmaned Aerial Vehicle (UAV) yang mampu bergerak secara otomatis, salah satu aplikasinya adalah sebagai penjejak pipa. Pada dasarnya digunakan sistem navigasi dengan bantuan global positioning system (GPS) dan kontrol PID untuk mengatur arah tujuan. Tetapi penggunaan GPS pada daerah yang tidak memiliki ruang terbuka bebas tidaklah memungkinkan dikarenakan pada daerah tersebut sinyal GPS menjadi lemah ataupun hilang. Sehingga dibutuhkan sebuah sistem yang dapat bekerja secara independen tanpa menggunakan GPS dalam proses penjejakan pipa. Digunakan proses pengolahan citra dengan contour finding dan region of interest yang terpadu dalam sebuah sistem yang terdiri dari Raspberry Pi dan Arduino Mega dalam memandu balon udara untuk menyusuri pipa, sehingga balon udara dapat berjalan secara otomatis menyusuri pipa. Serta digunakan kontrol logika fuzzy untuk menentukan kecepatan motor untuk mempertahankan keseimbangan dan untuk menyusuri pipa.

Hasil dari pengujian yang dilakukan dengan simulasi menggunakan pipa fleksibel berwarna biru pada tugas akhir ini menunjukan bahwa balon udara dapat menyusuri pipa dengan panduan pipa fleksibel. Selain menyusuri pipa fleksibel, balon udara juga dipertahankan kondisi roll-nya untuk selalu setimbang. Didapatkan kesalahan ukur dalam proses penjejakan pipa sebesar $4,7 \%$, sedangkan untuk kondisi roll didapatkan kesalahan sebesar $0,76 \%$.
\end{abstract}

Kata Kunci- UAV, Blimp, Tracking, OpenCV, IMU

\section{PENDAHULUAN}

$\mathrm{P}$ ADA dasarnya, balon udara adalah sebuah alat yang mampu terbang dengan kecepatan sangat rendah maupun mengambang di udara dengan perubahan ketinggian yang kecil. Dengan perkembangan teknologi robotik bidang penerbangan, penggunaan balon udara juga semakin berkembang. Saat ini balon udara banyak dipakai sebagai media komersial [1], selain itu penggunaan balon udara juga banyak digunakan untuk memonitoring cuaca dengan menerbangkan balon pada ketinggian sekitar 18-37 km [2]. Pengembangan balon sebagai pesawat tanpa awak banyak dilakukan pada bidang transportasi kargo [3], monitoring lingkungan [4], monitoring trafik kendaraan [5], dan juga pada bidang telekomunikasi [6].

Mengacu pada penggunaan balon untuk memonitoring trafik ataupun lingkungan, penggunaan sistem posisi dan penjejak menjadi komponen utama dalam sistem kontrol dan sistem navigasi balon udara. Sistem yang paling banyak dipakai saat ini merupakan sistem sederhana yang mengandalkan bantuan global positioning satellite (GPS) dengan titik lintang dan bujur yang sudah didefinisikan [7] dan sistem kontrol PID untuk mengatur ketinggian dan arah tujuan balon udara saat ini [8].

Tetapi pada realisasinya, dengan hanya menggunakan GPS untuk sistem navigasi masilah kurang. Dikarenakan penyimpangan yang terjadi masilah besar dengan orde meter [9]. Selain itu, GPS tidak dapat digunakan pada daerah dengan gedung-gedung tinggi atau pada tempat yang tidak memiliki ruang terbuka bebas (line-of-sight), dikarenakan sinyal GPS yang tidak dapat diterima pada daerah yang disebutkan sebelumnya.

Oleh karena itu diajukan sebuah metode navigasi baru dengan penggunaan pipa sebagai media penjejak dengan menggunakan kamera. Metode ini dapat bekerja secara independen tanpa bantuan GPS dalam navigasinya, dan dapat bekerja otomatis, serta balon dapat dikendalikan dari jarak jauh.

\section{DASAR TEORI}

\section{A. Akselerometer}

Akselerometer adalah alat yang digunakan untuk mengukur percepatan, mendeteksi dan mengukur getaran (vibrasi), dan mengukur percepatan akibat gravitasi (inklinasi) [11]. Akselerometer dapat digunakan untuk mengukur getaran pada mobil, mesin, bangunan, dan instalasi pengamanan. Akselerometer juga dapat diaplikasikan pada pengukuran aktivitas gempa bumi dan peralatan-peralatan elektronik, seperti permainan 3 dimensi, mouse komputer, dan telepon. Untuk aplikasi yang lebih lanjut, sensor ini banyak digunakan untuk keperluan navigasi. Percepatan merupakan suatu keadaan berubahnya kecepatan terhadap waktu. Bertambahnya suatu kecepatan dalam suatu rentang waktu disebut percepatan (akselerasi). Namun jika kecepatan semakin berkurang daripada kecepatan sebelumnya, disebut perlambatan (deakselerasi). Percepatan juga bergantung pada arah/orientasi karena merupakan penurunan kecepatan yang merupakan besaran vektor. Berubahnya arah pergerakan suatu benda akan menimbulkan percepatan pula. Untuk memperoleh data jarak dari sensor akselerometer, diperlukan proses integral ganda terhadap keluaran sensor [12].

\section{B. Giroskop}

Giroskop digunakan untuk mengukur orientasi berdasarkan prinsip momentum sudut. Giroskop konvensional adalah giroskop mekanikal, yang terdiri dari sebuah piringan yang berputar di sumbu putar. Sumbu putar ini terpasang pada suatu rangka yang disebut gimbal. Jumlah gimbal menentukan 


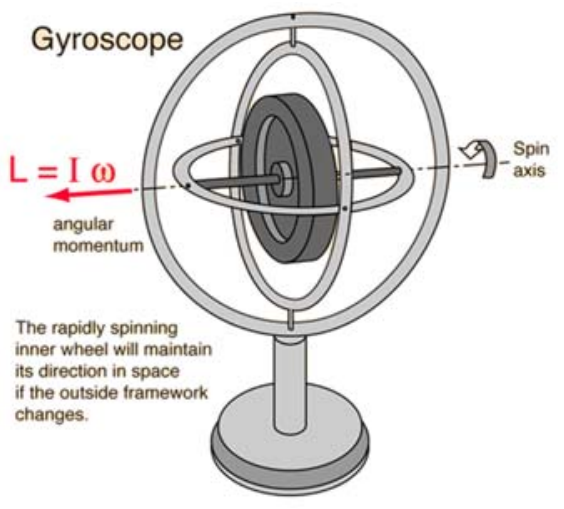

Gambar 1. Giroskop

jumlah aksis giroskop. Giroskop yang memiliki satu gimbal hanya dapat berputar dengan satu poros, giroskop yang memiliki dua gimbal dapat berputar dengan dua poros, dan giroskop yang memiliki tiga gimbal dapat berputar dengan tiga poros [13].

Prinsip rotor giro adalah kekakuan dalam ruang atau inersia giroskopik. Hukum pertama Newton menyatakan bahwa gaya total suatu benda adalah nol, maka gerak benda tidak akan terjadi.

$$
\sum \mathrm{F}=0 \text { (dalam kesetimbangan) }
$$

Rotor berputar dalam giroskop mempertahankan sikap konstan dalam ruang selama tidak ada gaya luar yang mengubah gerakannya. Stabilitas ini meningkat jika rotor memiliki massa yang besar dan berputar dengan cepat [14].

\section{Algoritma Madgwick AHRS [15]}

Madgwick AHRS adalah metode untuk proses orientasi dari sensor IMU dengan mengunakan alogaritma gradient decent untuk mengestimasi nilai orientasi dari ketiga sumbu yang ada pada giroskop,akselerometer dan magnetometer. Dimana diketahui bahwa giroskop pada IMU mempunyai nilai drift. Drift pada giroskop adalah pergeseran nilai derajat dari sumbu awal. Pada metode ini sudut-sudut euler dirubah menjadi Kuaternion [15].

Konsep dasar dari Magwick AHRS adalah mencari antara relatife frame atau yang biasa disebut perpindahan frame. Contoh dapat dilihat pada gambar di atas frame A relatife terhadap frame B. Dimana nilai perpindahan frame A ke frame B dapat direpresentasikan dalam bentuk kuaternion seperti persamaan 2 .

$$
\begin{aligned}
{ }_{B}^{A} \hat{q}= & {[q 0 q 1 q 2 q 3] } \\
= & {\left[\cos \frac{\theta}{2}-r x \sin \frac{\theta}{2}-r y \sin \frac{\theta}{2}-r z \sin \frac{\theta}{2}\right] } \\
& { }_{B}^{A} \hat{q} *={ }_{A}^{B} \hat{q}=[q 0-q 1-q 2-q 3]
\end{aligned}
$$

Bahwa untuk mencari nilai matrik yang baru, kedua matrik tersebut dikalikan dengan aturan cross product dimana dengan mengunakan aturan Hamilton. Seperti persamaan 4.

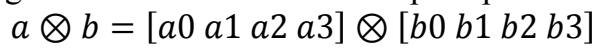

$$
=\left[\begin{array}{llll}
a_{0} b_{0} & -a_{1} b_{1} & -a_{2} b_{2} & -a_{3} b_{3} \\
a_{0} b_{1} & +a_{1} b_{0} & +a_{2} b_{3} & -a_{3} b_{2} \\
a_{0} b_{2} & -a_{1} b_{3} & +a_{2} b_{0} & +a_{3} b_{1} \\
a_{0} b_{3} & +a_{1} b_{2} & -a_{2} b_{1} & +a_{3} b_{0}
\end{array}\right]^{T}
$$

Pada gambar 2 dijelaskan alur dari metode madgwick. Untuk mengetahui representasi pergeserah frame berdasarkan sumbu garis normal gravitasi bumi menggunakan persamaan

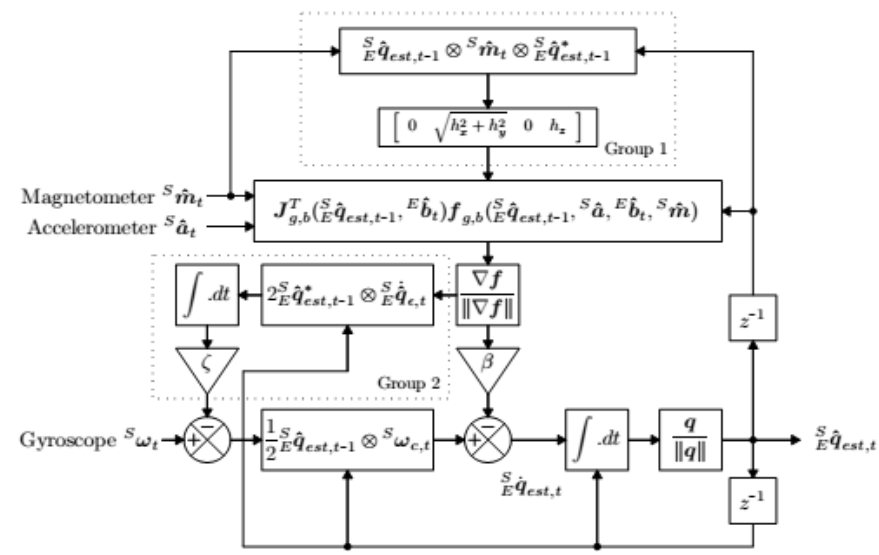

Gambar 2. Diagram Blok Algoritma AHRS Madgwick [15]

gradient decent. Dimana alogaritma gradient decent mempunyai fungsi seperti persamaan (5). Dengan demikian apabila dicross product ketiga quaternion tersebut akan menghasilkan matrik baru (9).

$$
\begin{aligned}
& f\left({ }_{E}^{S} \widehat{q}, E_{\hat{d}}, S_{\hat{s}}\right)={ }_{E}^{S} \hat{q} * \otimes E_{\hat{d}} \otimes{ }_{E}^{S} \hat{q}-S_{\hat{s}} \\
& { }_{E}^{S} \widehat{q}=[q 1-q 2-q 3-q 4] \\
& E_{\hat{g}}=\left[\begin{array}{llll}
0 & 0 & 0 & 1
\end{array}\right] \\
& S_{\hat{a}}=[0 \text { axayaz }] \\
& \mathrm{f}_{\mathrm{g}}\left({ }_{E}^{S} \hat{q}, S_{\hat{a}}\right)=\left[\begin{array}{c}
2(q 2 q 4-q 1 q 3)-a x \\
2(q 1 q 2+q 3 q 4)-a y \\
2\left(\frac{1}{2}-q_{2}{ }^{2}-q_{3}{ }^{2}\right)-a z
\end{array}\right]
\end{aligned}
$$

Setelah proses untuk mencari nilai $f$, kemudian dicari hasil dari matrik jacobi sesuai degan persamaan (10).

$$
\mathrm{J}_{\mathrm{g}}\left({ }_{E}^{S} \widehat{q}\right)=\left[\begin{array}{cccc}
-2 q 3 & 2 q 4 & -2 q 1 & 2 q 2 \\
2 q 2 & 2 q 1 & 2 q 4 & 2 q 3 \\
0 & -4 q 2 & -4 q 3 & 0
\end{array}\right]
$$

Kemudian setelah kedua matrik $\mathrm{f}$ dan $\mathrm{J}$ telah didapatkan hasil.Untuk mencari nilai dari matrik gradien decent adalah sesuai dengan persamaan (11).

$$
\nabla \mathrm{f}=\mathrm{j}^{\mathrm{T}} \times \mathrm{f}
$$

Untuk mencari nilai estimasi dari kuaternion, kuaternion pada giroskop dikurangkan dengan hasil kuaternion pada proses alogaritma gradien decent yang sudah dibagi dengan nilai normalisasi dan dikalikan dengan nilai pembobotan(beta), sesuai dengan persamaan (12).

$$
{ }_{\mathrm{E}}^{\mathrm{S}} \dot{\mathrm{q}} \mathrm{est}, \mathrm{t}={ }_{\mathrm{E}}^{\mathrm{S}} \dot{\mathrm{q}} \omega, \mathrm{t}-\beta \frac{\nabla \mathrm{f}}{\|\nabla \mathrm{f}\|}
$$

Untuk mencari nilai $\beta$ atau pembobotan dapat menggunakan persamaan (13).

$$
\beta=\left\|\frac{1}{2} \hat{q} \otimes\left[0 \bar{\omega}_{\max } \bar{\omega}_{\max } \bar{\omega}_{\max }\right]\right\| \sqrt{\frac{3}{4}} \bar{\omega}_{\max }
$$

\section{Computer Vision}

Computer Vision adalah pencitraan komputer dimana aplikasi tidak melibatkan manusia dalam sebagai salah satu cabang ilmu pengetahuan yang mempelajari bagaimana komputer dapat mengenali obyek yang diamati atau diobservasi. Cabang ilmu ini bersama kecerdasan buatan (Artificial Intelligence) akan mampu menghasilkan sistem kecerdasan visual (Visual Intelligence System) [16]. 
Proses-proses dalam computer vision dapat dibagi menjadi tiga aktivitas, yaitu:

1. Memperoleh atau mengakuisisi citra digital.

2. Melakukan teknik komputasi untuk memproses atau memodifikasi citra.

3. Menganalisis dan mengintepretasi citra dan menggunakan hasil pemrosesan untuk tujuan tertentu.

\section{E. Warna}

Dengan menggunakan 3 buah reseptor manusia dapat membedakan banyak warna. Warna tricromatic RGB dalam sistem grafis umumnya menggunakan 3 byte. Mesin dapat membedakan antara berbagai kode warna, namun perbedaan tersebut belum tentu dapat menunjukan perbedaan yang dapat ditangkap oleh mata manusia. Tiap 3 byte pada pixel RGB mencangkup 1 byte pixel untuk tiap warna Red (merah), Green (hijau), Blue (biru) [17].

Gambar direpresentasikan sebagai matrik dengan elemen integer atau pixel. Biasanya pixel tidak disimpan dalam bentuk matrik sederhana, namun menggunakan data yang lebih rumit. Dan terkadang memudahkan secara matematis jika kita beranggapan gambar berwarna sebagai matrik dari vektor tiga dimensi [18].

\section{F. Logika Fuzzy}

Logika fuzzy adalah metodologi sistem kontrol pemecahan masalah, yang cocok untuk diimplementasikan pada sistem, mulai dari sistem yang sederhana, sistem kecil, embedded system, jaringan PC, multi- channel atau workstation berbasis akuisisi data, dan sistem kontrol. Metodologi ini dapat diterapkan pada perangkat keras, perangkat lunak, atau kombinasi keduanya [19].

\section{G. Operasi Himpunan Fuzzy}

Operasi himpunan fuzzy diperlukan untuk proses inferensi atau penalaran. Dalam hal ini yang dioperasikan adalah derajat keanggotaanya. Derajat keanggotaan sebagai hasil dari operasi dua buah himpunan fuzzy disebut sebagai fire strength atau $\alpha$ predikat [19].

Ada beberapa hal yang perlu diketahui dalam memahami sistem fuzzy, yaitu:

1. Variabel fuzzy merupakan variabel yang hendak dibahas dalam suatu sistem fuzzy.

2. Himpunan fuzzy merupakan suatu grup yang mewakili suatu kondisi atau keadaan tertentu dalam suatu variabel fuzzy.

3. Semesta pembicaraan adalah keseluruhan nilai yang diperbolehkan untuk dioperasikan dalam suatu variabel fuzzy.

Domain himpunan fuzzy adalah keseluruhan nilai yang diizinkan dalam semesta pembicaraan dan boleh dioperasikan dalam suatu himpunan fuzzy [20][21].

\section{PERANCANGAN SISTEM}

\section{A. Diagram Blok Sistem}

Sistem yang dirancang terdiri dari lima bagian besar yaitu sensor, Raspberry Pi, Arduino Mega 2560, H-Bridge, dan Aktuator. Untuk sensor, terdiri dari sensor akselerometer, giroskop dan magnetometer yang tergabung menjadi satu pada sensor Inertial Measurement Unit (IMU). Serta kamera yang digunakan pada proses penjejakan pipa dengan bantuan pengolahan citra yang ada pada Raspberry Pi. Penggunaan Raspberry Pi, selain sebagai pengolah citra, juga sebagai user interface utama yang dapat diakses melalu layar atau remote desktop. Seluruh data dari sensor IMU diolah langsung dengan algoritma Madgwick AHRS untuk didapatkan nilai roll-nya, yang kemudian diolah dengan logika fuzzy untuk menstabilkan gerak roll dari balon udara yang digunakan. Sedangkan data yang telah diolah oleh pengolah citra yang terdapat pada Raspberry Pi, ditransfer dengan komunikasi serial menuju Arduino Mega 2560 untuk diolah dengan logika fuzzy untuk memandu balon udara dalam mengikuti dan menjejak pipa gas.

\section{B. Kalkulasi Penjejak Pipa}

Proses pengambilan citra dan filter warna dilakukan pada Raspberry Pi 3, bahasa yang dipakai adalah bahasa python dengan versi 3.4. Proses pengambilan citra dan filter warna dibantu dengan library OpenCV 3.0. Kemudian citra yang didapat dirubah menjadi HSV yang dilanjutkan pemfilteran warna

Dari gambar 3.11 diatas dilakukan pengambilan gambar terlebih dahulu dengan format BGR, setelah itu gambar

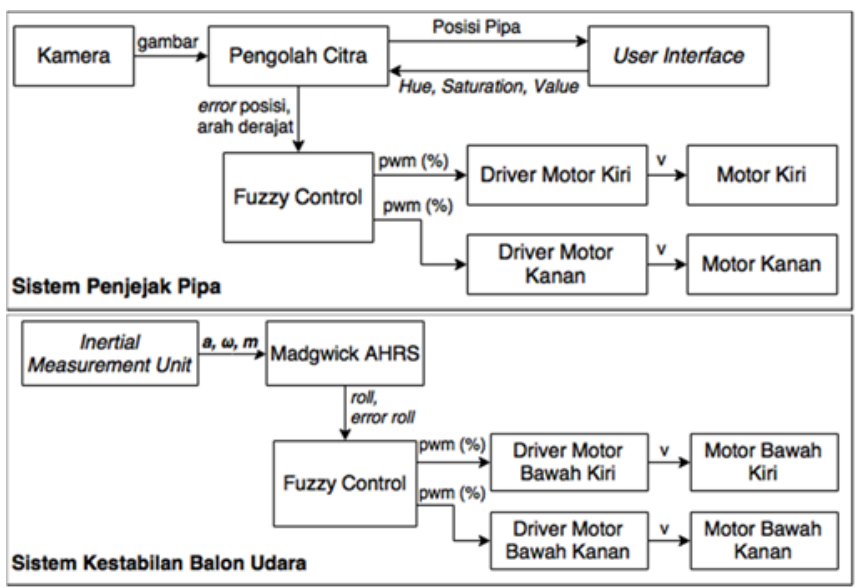

Gambar 3. Blok Diagram Sistem yang Dirancang

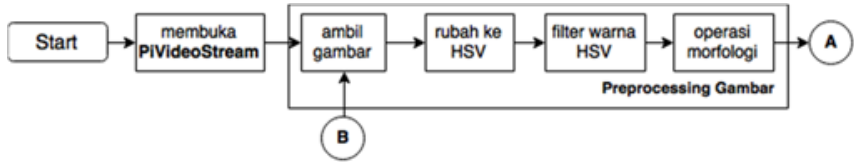

Gambar 4. Diagram Alir Proses Preprocessing

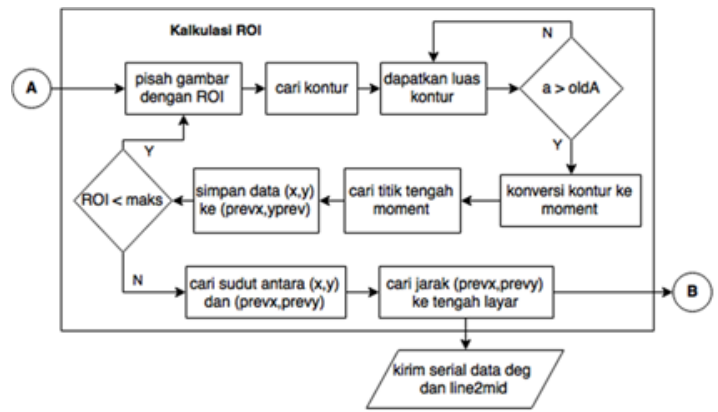

Gambar 5. Diagram Alir Proses Kalkulasi Perbelokan 


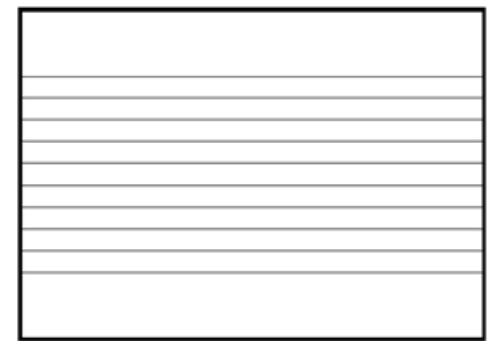

Gambar 6. Gambaran Lokasi ROI yang Diinginkan

dirubah formatnya menjadi HSV yang kemudian gambar difilter dengan masukan dari pengguna berupa Hue, Saturation, dan Value. Citra yang didapat dimorfologikan terlebih dahulu. Setelah itu citra yang didapat dapat dimasukan kedalam program penjejak pipa. Penjejakan pipa menggunakan metode ROI (Region of Interest) dan contour finding.

Metode ROI digunakan untuk mempermudah proses contour finding. Setiap kotak yang terbentuk dicari posisi konturnya dengan fungsi findContours setelah itu dicari kontur terluas dengan memanfaatkan fungsi contourArea. setelah didapatkan posisinya, dicari nilai tengah dari kontur yang ditemukan dengan mengubah kontur menjadi moments agar dapat diakses secara array. Nilai $\mathrm{x}$ dan $\mathrm{y}$ terletak pada kombinasi posisi array $\mathrm{m} 10, \mathrm{~m} 01$ dan $\mathrm{m} 00$. Untuk mendapatkan nilai $\mathrm{x}$ dan y yang benar digunakan rumus:

$$
x=\frac{m 10}{m 00} \text { dan } y=\frac{m 01}{m 00}
$$

Setelah didapatkan nilai $\mathrm{x}$ dan $\mathrm{y}$ pada setiap kotak ditemukan, maka jalur dari pipa yang ingin dijejak dapat dikalkulasikan dengan rumus:

$$
\operatorname{deg}=\tan ^{-1} \frac{y 1-y 2}{x 1-x 2} *\left(\frac{180}{\pi}\right)
$$

\section{Perhitungan Fuzzy untuk Kecepatan Motor}

Prinsip dasar dalam perancangan basis aturan kontrol logika fuzzy sesuai dengan tabel 1 adalah sebagai berikut, jika variabel proses roll telah mencapai nilai yang diinginkan, perubahan error bernilai nol, balon udara berada dalam kondisi stabil dan pengendali logika fuzzy dipertahankan konstan. Namun apabila sebaliknya, nilai variabel belum sesuai dengan

Tabel 1. Basis Aturan Fuzzy Motor Kiri-Kanan

\begin{tabular}{|c|c|c|c|c|c|}
\hline $\begin{array}{c}\text { line2mid } \\
\text { direction }\end{array}$ & Fkiri & \multicolumn{1}{|c|}{ Kiri } & Tengah & Kanan & Fkanan \\
\hline eKiri & PKi, CKa & NKi, NKa & NKi, CKa & PKi, CKa & CKi, PKa \\
\hline eLurus & PKi, CKa & NKi, CKa & CKa, CKa & NKi, CKa & CKi, PKa \\
\hline eKanan & PKi, CKa & CKi, PKa & CKa, CKi & NKi, NKa & CKi, PKa \\
\hline
\end{tabular}

Tabel 2. Basis Aturan Fuzzy Motor Bawah Kiri-Bawah Kanan

\begin{tabular}{|c|c|c|c|c|c|}
\hline e-roll & Fkiri & Kiri & Tengah & Kanan & Fkanan \\
\hline eKiri & CBKi, PBKa & CBKi, PBKa & NBKi, PBKa & PBKi, NBKa & PBKi, CBKa \\
\hline eTengah & CBKi, PBKa & NBKi, PBKa & PBKi, PBKa & PBKi, NBKa & PBKi, CBKa \\
\hline eKanan & CBKi, PBKa & NBKi, PBKa & PBKi, NBKa & PBKi, CBKa & PBKi, CBKa \\
\hline
\end{tabular}

\section{Keterangan:}

$\begin{array}{llll}\text { CBKi } & =\text { Cepat Bawah Kiri, } & \text { CKi } & =\text { Cepat Kiri, } \\ \text { NBKi } & =\text { Normal Bawah Kiri, } & \text { NKi } & =\text { Normal Kiri, } \\ \text { PBKi } & =\text { Pelan Bawah Kiri, } & \text { PKi } & =\text { Pelan Kiri, } \\ \text { CBKi } & =\text { Cepat Bawah Kiri, } & \text { CKi } & =\text { Cepat Kiri, } \\ \text { NBKi } & =\text { Normal Bawah Kiri, } & \text { NKi } & =\text { Normal Kiri, } \\ \text { PBKa } & =\text { Pelan Bawah Kanan. } & \text { PKa } & =\text { Pelan Kanan. }\end{array}$

yang diinginkan, dan balon mengalami roll maka sinyal kendali berubah sesuai dengan besarnya nilai error roll dan nilai roll saat ini.

Sedangkan untuk kendali logika fuzzy pada perbelokan sesuai dengan tabel 2, terdapat nilai error yang menandakan balon tidak berada pas diatas pipa dan nilai direksi pipa yang menandakan pipa berbelok. Jika nilai error nol dan direksi juga nol, balon udara berada pas diatas pipa yang sedang dijejak.

\section{HASIL DAN ANALISA}

\section{A. Realisasi Desain Balon Udara}

Pada tugas akhir ini digunakan dua balon udara air swimmer yang akan diisi dengan helium. Volume dari balon udara ini adalah $0.1274 \mathrm{~m} 3$. Dua balon udara air swimmer mempunyai volume untuk diisi helium sebesar $0.2548 \mathrm{~m} 3$.

Gambar 8 menunjukkan lokasi daripada kamera beserta motor yang digunakan. Pada alat yang dibuat, digunakan dua set motor yaitu motor bawah dan mtor samping. Hal ini

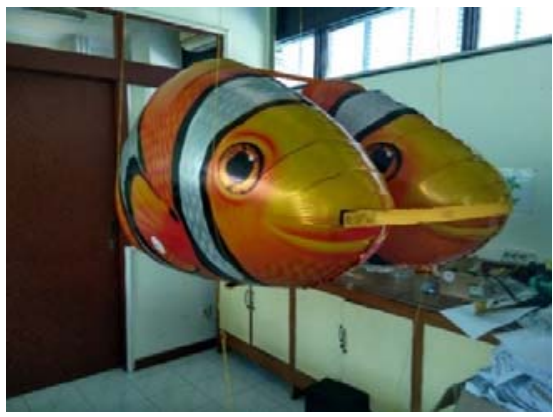

Gambar 7. Realisasi Balon Udara yang Digunakan
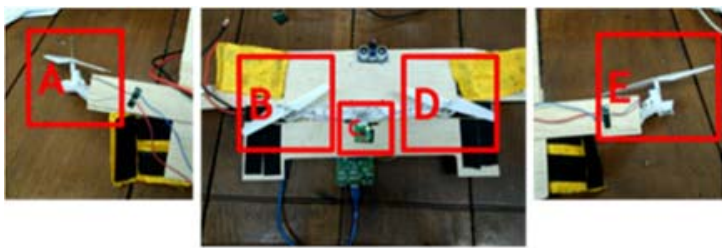
Keterangan:
A $=$ Motor Samping Kanan
$\mathrm{B}=$ Motor Bawah Kanan
$\mathrm{C}=$ Kamera
$\mathrm{D}=$ Motor Bawah Kiri
$\mathrm{E}=$ Motor Samping Kiri
Dimasukkan dalam gambar

Gambar 8. Realisasi Kotak Kontrol dan Lokasi Motor

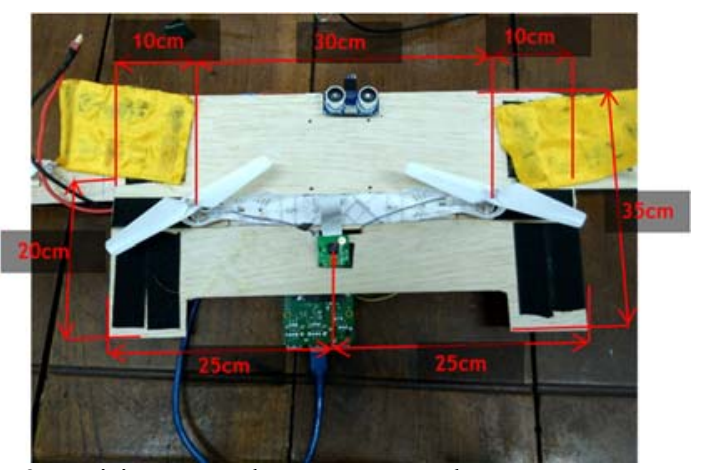

Gambar 9. Posisi Kamera dan Motor Bawah 
digunakan untuk mempermudah perhitungan belok serta perhitungan dari keseimbangan. Gambar 9 menunjukkan ukuran dari lokasi penempatan kamera, motor bawah kiri dan kanan, serta ukuran kotak kontrol yang digunakan.

\section{B. Pengujian Roll Algoritma Madgwick}

Pengujian ini dilakukan untuk mengukur performa dari filter Madgwick untuk Inertial Measurement Unit yang digunakan. Didapatkan data sesuai pada gambar 11. Dari data yang didapatkan, dapat disimpulkan bahwa filter Madgwick memberikan data yang akurat dengan error rata-rata sebesar $5,3^{\circ}$ untuk hasil pitch dan $0,3^{\circ}$ untuk hasil roll.

\section{Pengujian Jarak Perhitungan dan Jarak Sesungguhnya dengan Menggunakan Pengolahan Citra}

Pengujian ini dilakukan untuk mengetahui error dari perhitungan berdasarkan pengolahan citra dibandingkan dengan jarak sesungguhnya. Didapatkan data sesuai pada gambar 12. Berdasarkan data yang diperoleh, metode penjejakan pipa dengan menggunakan ROI dan contour finding mampu menjejak pipa dengan ketelitian $0.3 \mathrm{~cm}$

Tabel 3. Data Pengujian Keseimbangan

\begin{tabular}{|c|c|c|c|c|}
\hline $\begin{array}{c}\text { Detik } \\
\text { (s) }\end{array}$ & $\begin{array}{c}\text { Sudut Uji } \\
\left({ }^{\circ}\right)\end{array}$ & $\begin{array}{l}\text { Kiri } \\
(\%)\end{array}$ & $\begin{array}{c}\text { Kanan } \\
(\%)\end{array}$ & $\begin{array}{c}\text { Roll } \\
\left({ }^{\circ}\right)\end{array}$ \\
\hline 1 & \multirow{20}{*}{ 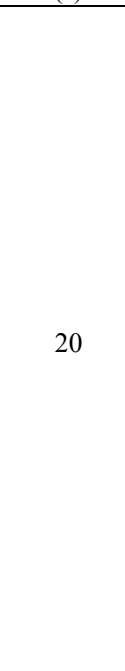 } & 14 & 35 & 20 \\
\hline 2 & & 14 & 33 & 17 \\
\hline 3 & & 13 & 27 & 10 \\
\hline 4 & & 13 & 21 & 5 \\
\hline 5 & & 18 & 13 & -3 \\
\hline 6 & & 26 & 13 & -9 \\
\hline 7 & & 30 & 14 & -13 \\
\hline 8 & & 31 & 14 & -15 \\
\hline 9 & & 29 & 13 & -12 \\
\hline 10 & & 27 & 13 & -10 \\
\hline 11 & & 25 & 13 & -8 \\
\hline 12 & & 21 & 13 & -5 \\
\hline 13 & & 17 & 13 & -2 \\
\hline 14 & & 13 & 17 & 2 \\
\hline 15 & & 13 & 21 & 5 \\
\hline 16 & & 13 & 18 & 3 \\
\hline 17 & & 13 & 15 & 1 \\
\hline 18 & & 15 & 13 & -1 \\
\hline 19 & & 13 & 15 & 1 \\
\hline 20 & & 15 & 13 & -1 \\
\hline
\end{tabular}

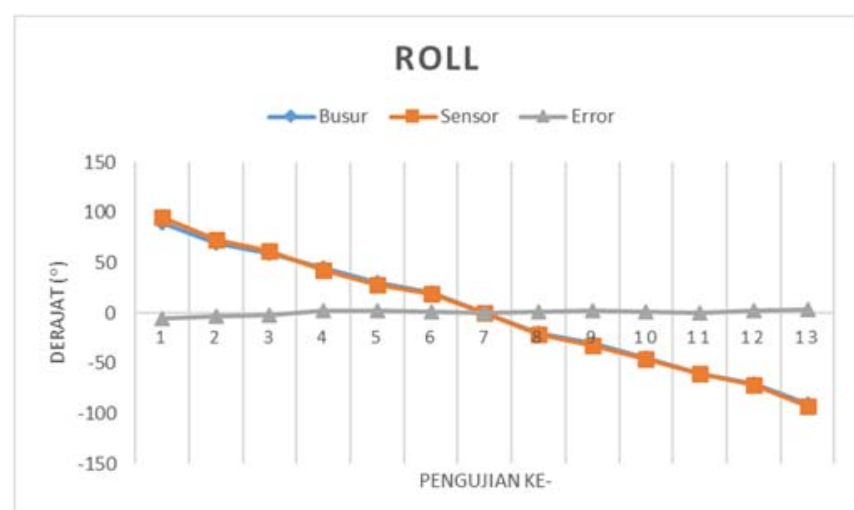

Gambar 11. Grafik Pembacaan Roll dengan Filter Madgwick
D. Pengujian Respon Keseimbangan

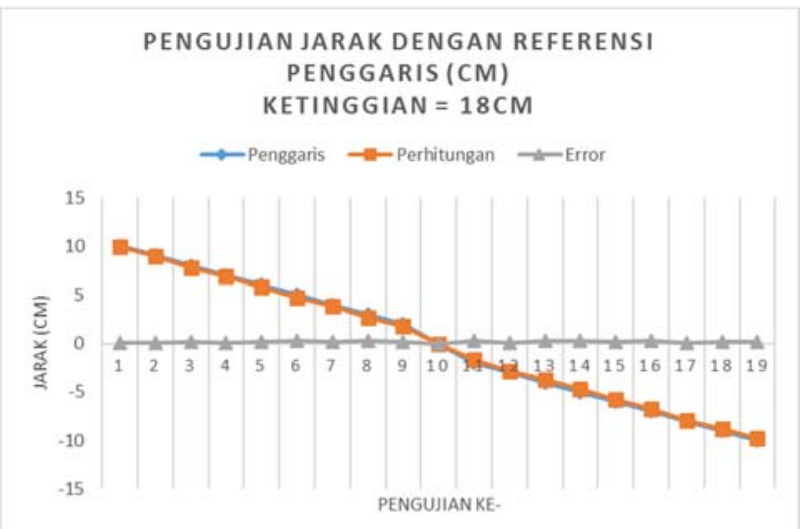

Gambar 12. Grafik Pengujian Jarak dengan Kamera

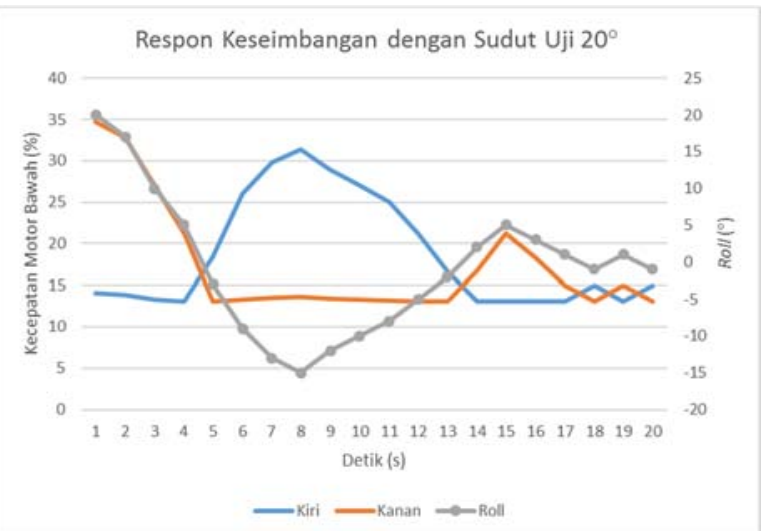

Gambar 13. Grafik Pengujian Respon Keseimbangan.

Tabel 4. Data Pengujian Keseimbangan

\begin{tabular}{|c|c|c|c|c|}
\hline $\begin{array}{l}\text { Detik } \\
\text { (s) }\end{array}$ & $\begin{array}{c}\text { Sudut Uji } \\
\left({ }^{\circ}\right)\end{array}$ & $\begin{array}{l}\text { Kiri } \\
(\%)\end{array}$ & $\begin{array}{c}\text { Kanan } \\
(\%)\end{array}$ & $\begin{array}{c}\text { Roll } \\
\left({ }^{\circ}\right)\end{array}$ \\
\hline 1 & \multirow{21}{*}{-20} & 35 & 14 & -20 \\
\hline 2 & & 33 & 14 & -18 \\
\hline 3 & & 28 & 13 & -11 \\
\hline 4 & & 23 & 13 & -6 \\
\hline 5 & & 13 & 18 & 3 \\
\hline 6 & & 13 & 25 & 8 \\
\hline 7 & & 13 & 29 & 12 \\
\hline 8 & & 14 & 31 & 14 \\
\hline 9 & & 13 & 29 & 12 \\
\hline 10 & & 13 & 26 & 9 \\
\hline 11 & & 13 & 23 & 6 \\
\hline 12 & & 13 & 21 & 5 \\
\hline 13 & & 13 & 18 & 3 \\
\hline 14 & & 15 & 13 & -1 \\
\hline 15 & & 21 & 13 & -5 \\
\hline 16 & & 17 & 13 & -2 \\
\hline 17 & & 15 & 13 & -1 \\
\hline 18 & & 13 & 15 & 1 \\
\hline 19 & & 13 & 17 & 2 \\
\hline 20 & & 13 & 15 & 1 \\
\hline 21 & & 15 & 13 & -1 \\
\hline
\end{tabular}

Pengujian ini dilakukan untuk mengetahui respon dari sistem keseimbangan pada balon yang telah dirancang. Didapatkan hasil sesuai pada tabel 5 dan 6 . 


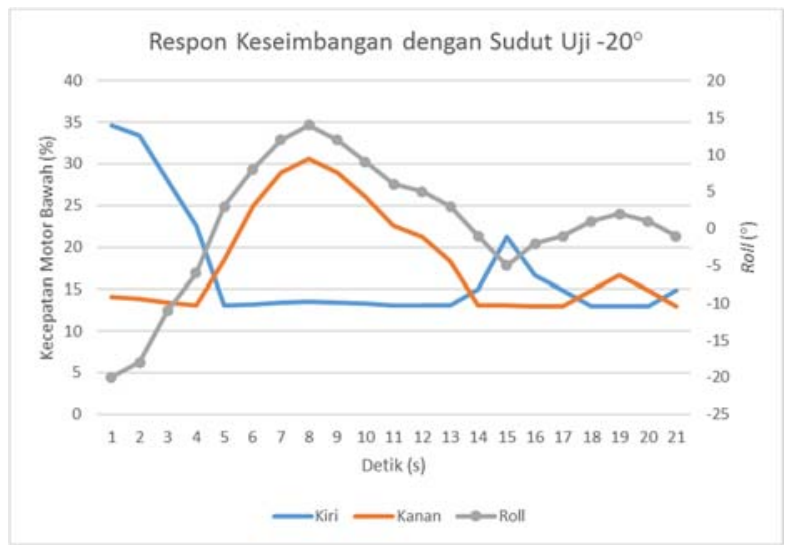

Gambar 14. Grafik Pengujian Respon Keseimbangan

\section{KESIMPULAN}

Telah dirancang balon udara dengan kendali yang terdiri dari image processing untuk menjejak pipa dan sensor IMU dengan kontrol fuzzy untuk mempertahankan keseimbangan. Berdasarkan data yang diperoleh, metode penjejakan pipa dengan menggunakan ROI dan contour finding mampu menjejak pipa dengan ketelitian $0.3 \mathrm{~cm}$ dan data yang didapat dari pengujian sensor giroskop dapat disimpulkan bahwa metode filter magdwick mampu memfilter data giroskop dengan kesalahan rata-rata sebesar $0,76 \%$ atau $0.3^{\circ}$. Serta Penggunaan logika fuzzy dapat diterapkan pada sistem kontrol pergerakan balon dan keseimbangan balon, dengan variable yang digunakan berupa jarak error posisi dan derajat arah pipa untuk sistem motor pergerakan balon, serta data giroskop roll dan error roll untuk sistem keseimbangan balon udara.

\section{DAFTAR PUSTAKA}

[1] Anonim. "E-Ballon" <URL: http://www.eballoon.org/balloon/ balloon-usages.html>. Mei. 2016

[2] Anonim. "Intro to Weather Balloons" <URL: http://www.highaltitudescience.com/pages/intro-to-weatherballoons>. Mei. 2016

[3] Skuza, J. R., Park, Y., \& Kim, H. J. et al. "Feasibility study of cargo airship transportation systems powered by new green energy technologies". NASA Center for AeroSpace Information. 2014

[4] Elfes, A., Bueno, S. S., Bergerman, M., \& Ramos, J. G., Jr. “A semi-autonomous robotic airship for environmental monitoring missions". In Proceedings of the IEEE international conference on robotics and automation. Leuven. Belgium. Mei. 1998

[5] Kanistras, K., Martins, G., \& Rutherford, M. J., et al. "Survey of unmanned aerial vehicles (UAVs) for traffic monitoring". In Handbook of Unmanned Aerial Vehicles. Netherlands. 2014

[6] Yang, Y., Wu, J., \& Zheng, W. "Design, modeling and control for a stratospheric telecommunication platform". Acta Astronautica. 80(November-December). 181-189. 2012

[7] Ramos, J. G., Jr., Carneiro de Paiva, E., \& Azinheira, J. R., et al. "Autonomous flight experiment with a robotic unmanned airship". In IEEE international conference on robotics and automation. Seoul. Korea. 2001

[8] de Paiva, E. C., Bueno, S. S., \& Gomes, S .B. V., et al. "A control system development environment for AURORA's semi-autonomous robotic airship". In 1999 IEEE international conference on robotics and automation. Detroit. USA. 1999

[9] Anonim, "Explanation of GPS/GNSS Drift" <URL: https://sites.aces.edu/group/crops/precisionag/Publications/Timely\%
20Information/GPS-GNSS_Drift.pdf>. Mei. 2016

[10] D. Jeronimo, R. Alcacer dan F. C. Alegria. "Line Following and Ground Vehicle Tracking by an Autonomous Aerial Blimp". Institute for Systems and Robotics Lisboa. 2016

[11] G. Pang dan H. Liu. "Evaluation of a low-cost MEMS accelerometer for distance measurement". Journal of Intelligent and Robotic System 30. 2001

[12] K. Seifert dan O. Camacho. "Implementing Positioning Algortihms Using Accelerometers". Freescale Semiconductor. 2007

[13] A. Noth, S. Fux dan S. Bouabdallah. "Inertial Measurement Unit" <URL: http://sky-sailor.ethz.ch/docs/Development_of_a_Plannar _Low_Cost_Inertial_Measurement_Unit_for_UAVs and ${ }_{\text {_ }}$ MAVs (Fux2008).pdf>. Januari. 2016

[14] Anonim. "hyperphysic.phy-astr.gsu.edu". <URL http://hyperphysic.phy-astr.gsu.edu/hbase/gyr.html. Mei. 2016

[15] S. O. Madgwick. "An Efficient Orientation Filter for Inertial and Inertial/Magnetic Sensor Arrays". Report $x$-io and University of Bristol (UK). 2010

[16] W. R. Hamilton. "Elements of Quaternions". Longmans: Green \& Company. 1866

[17] R. Munir. "Pengolahan Citra Digital dengan Pendekatan Algoritmik Informatika". Bandung. 2004

[18] S. I. Syafi'i. "Open Computer Vision (OpenCV)". 2011

[19] L. Shapiro dan G. C. Stockman. "Computer Vision”. Prentice Hall. 2001

[20] T. Pavlidis. "Algorithms for Graphic and Image Processing". 1882.

[21] D. Davies, D. Bathurst dan R. Bathurst. "The Telling Image: The Changing Balance Between Pictures and Words in Technological Age". Clarendon Pr. 1990

[22] T. Sutojo, E. Mulyanto dan V. Suhartono. "Kecerdasan Buatan". Yogyakarta: Andi Offset. 2011

[23] S. Kusumadewi. "Artificial Intelligence (Teknik dan Aplikasinya)". Yogyakarta: Graha Ilmu. 2003

[24] R. AS. "Modul Pembelajaran Rekayasa Perangkat Lunak". Bandung. 2011 